\title{
Simulation of Electric Energy Consumption Monitoring System Air Conditioning Equipment
}

\author{
Ali A. S. Ramschie \\ Department of Computer \\ Engineering \\ Manado State Polytechnic
}

\author{
Johan F. Makal \\ Department of Electrical \\ Engineering \\ Manado State Polytechnic
}

\author{
Veny V. Ponggawa \\ Department of Computer \\ Engineering \\ Manado State Polytechnic
}

\begin{abstract}
Using of air conditioning equipment to cool the room, has become one of the needs especially in areas with hot climates. In operation, users do not know how much electricity consumption is consumed by air conditioning equipment, so that it can potentially cause electricity waste.

This research aims to make a system simulation through proteus simulation program, which can monitor electrical energy consumption from air conditioning equipment, through input data from the current sensor that is processed by the controller, then informed through the LCD display as information on the amount of electrical energy consumption from air conditioning equipment.

From the test results, it was found that, systems that are made can monitor the amount of electrical energy consumption from air conditioning equipment, where the monitoring results are displayed through the LCD display. The information displayed is the amount of electricity consumption in watt hour (Wh) and the amount of the price paid in rupiah $(R p)$.
\end{abstract}

\section{Keywords}

Simulation, Proteus, Controller, Electrical Energy, Air Conditioning.

\section{INTRODUCTION}

To achieve high quality of Air Conditioning work, good maintenance of each component is a key requirement for optimum cooling [1][2].

In addition, it is necessary to monitor the consumption of electrical energy from $\mathrm{AC}$ equipment, to find out how much electricity is consumed by the equipment, so that it can regulate the work of $\mathrm{AC}$ equipment, so that it can avoid electricity waste.

To produce a monitoring system for electrical energy consumption of $\mathrm{AC}$ equipment, then integrated support equipment is needed, such as: Arduino Uno controller, which works as a data processing center [3][4], current sensor acs712, where the current sensor is a sensor that can detect the amount of current, through the detection of electricity flowing on the copper cable contained in it. Electricity flowing on the copper cable will produce a field magnet, then the resulting magnetic field is captured by the integrated Hall IC and converted to proportional voltage. To determine the amount of output voltage from acs 712 , that is, using the equation:

V Out $=2.5 \pm(0.186 * I)$

Where $I$ is the current detected in amperes [5][6][7]. To display energy information from air conditioning equipment, use the module liquid crystal display (lcd), where information is displayed in the form of information on the amount of electricity consumption in watt hour (Wh) and the amount of the price paid in rupiah $(R p)$.

To activate the electrical energy monitoring system for air conditioning equipment, need software embedded in the ATMEGA 328 controller installed on the Arduino Uno board. Software created through the program Arduino IDE, by referring to the program algorithm in the form flowchart, which describes the working order of the program for monitoring the electrical energy consumption system of air conditioning equipment [8][9].

Researches related to research are:

1. Chiou,et al (2008), published in the journal Energy and Buildings entitled "The study of energy-saving strategy for direct expansion air conditioning system", in which research is related to energy-saving procedures in DX Air Conditioning system, with periodic downtime method, by setting the system's operating period and the system shutdown period of two ACs [10].

2. Widell, et al. (2009) published in the International Journal of Refrigeration under the title "Reducing power consumption in multi-compressor refrigeration system", using linear programming model to minimize the compressor's electric energy consumption, the compressor's operation will be optimized according to the required load [11].

3. Zhou, et al (2007), published in the journal Energy and Buildings entitled "Energy simulation in the variable refrigerant flow air-conditioning system under cooling conditions", this research compare the energy consumption from air conditioning system with 3 different methods, namelyVariableRefrigerantFlow (VRF) system, Variable Air Volume (VAV) system and fan-coil plus fresh air (FPFA) system. The study was conducted with a simulation using the Energy Plus software. Simulation results show that the energy-saving potential of the VRF system reaches $22.2 \%$ and $11.7 \%$, compared to VAV and FPFA systems [12].

\section{METHODOLOGI}

The method used in this research is design and manufacturing methods, which include system design and manufacture, in the form of an integrated control circuit and software to run the entire system. The system testing process is done by simulating it through Proteus simulation.

\subsection{System Design}

System design is made to facilitate the system development process by modeling it in the form of a Block Diagram, as shown in Figure 1.

Description of Figure 1:

- Arduino Uno R3 microcontroller serves as a regulator of the entire system.

- Current sensor, serves as a detector of changes in electric 
- LCD screen, serves as an information medium to display the amount of electricity consumption in watt hour (Wh) and the amount of price paid in rupiah (Rp.).

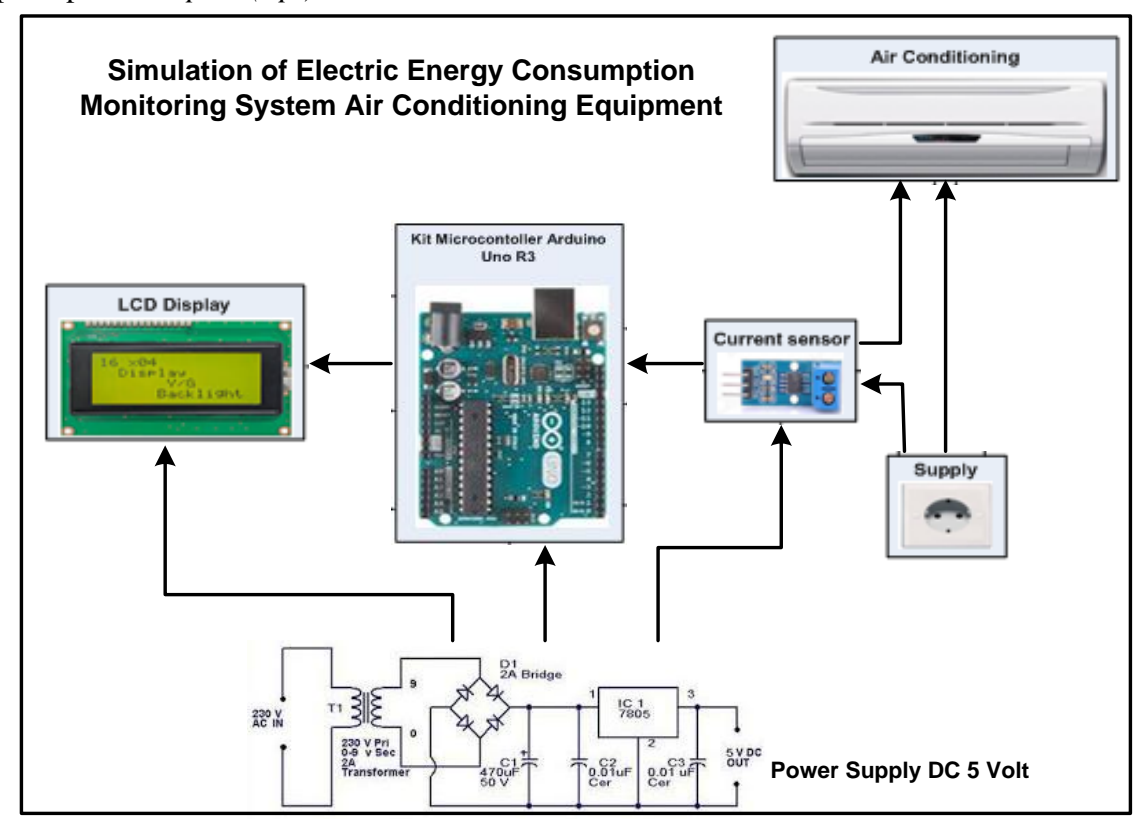

Fig. 1 Block diagram system

\subsection{Flowchart System (Algorithm)}

Flowchart system (algorithm), is a representation of the workflow or process to run the system, where the resulting algorithm is translated in the form of software, which will be embedded into the controller to run system work.. This system flowchart is shown in Figure 2.

Description algorithm of the system as follows:

- When the system is first activated, then the initial process carried out is the Initialization section I / O and the variable, where this section is part of the program for setting the input and output sections as well as the variables used in the system work operation.

- The next step is to read the input data from the current sensor in the form of a variable voltage.

- If there is no readable voltage (input voltage $=0$ ), then the system will inform to the LCD display, that the air conditioning is off.

- If the voltage value is read greater than 0 , then the system will enter the program section which functions to change the value of the incoming analog voltage, into digital data (because the controller cannot read analog data, so it must be converted into digital data)

- After analog data is converted to digital data, Then the system will enter the program section to calculate the amount of electrical energy (Wh) and the price paid $(R p)$ of air conditioning usage.

- The system will then inform to the LCD display, information about the amount of electricity consumption $(\mathrm{Wh})$ and the price of the payment $(R p)$ to the $\mathrm{AC}$ operation.

- The process of monitoring the consumption of electrical energy from air conditioning equipment, will continue continuously, until the system is deactivated.

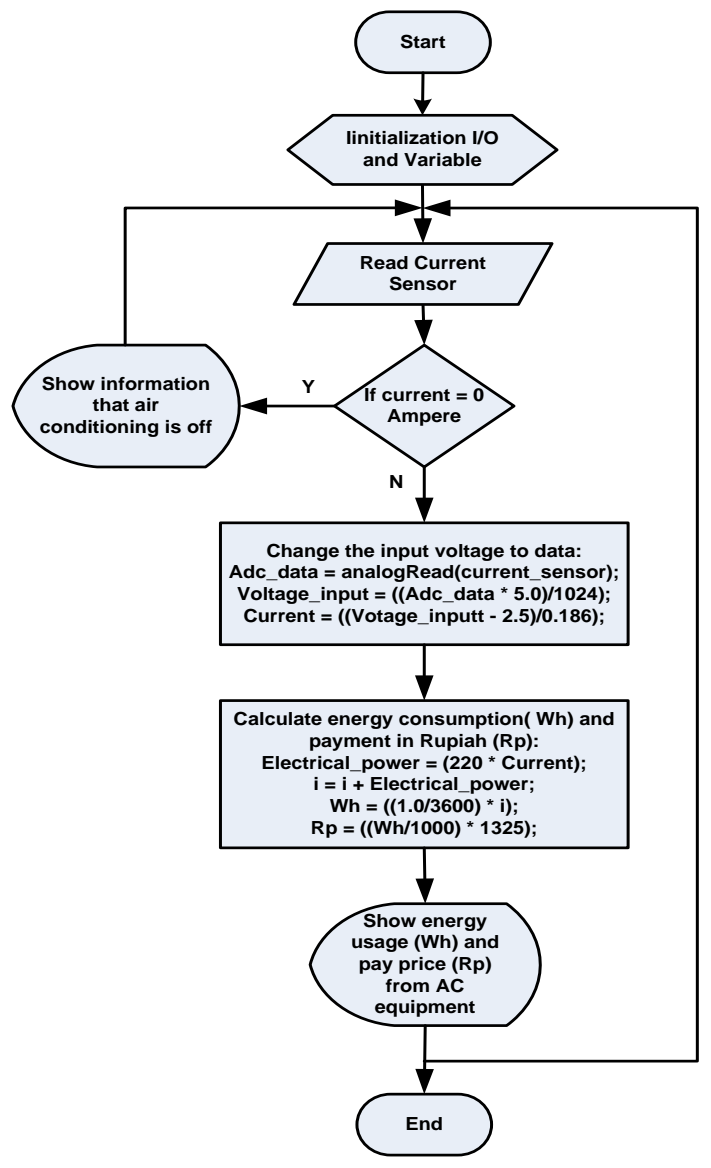

Fig.2 Flowchart system 


\subsection{Sistem Design}

The system design refers to the block diagram that has been created, where the current sensor module and LCD display module are integrated with the Arduino Uno controller which functions as the overall work controller of the system. Figure 3 shows the system design created.

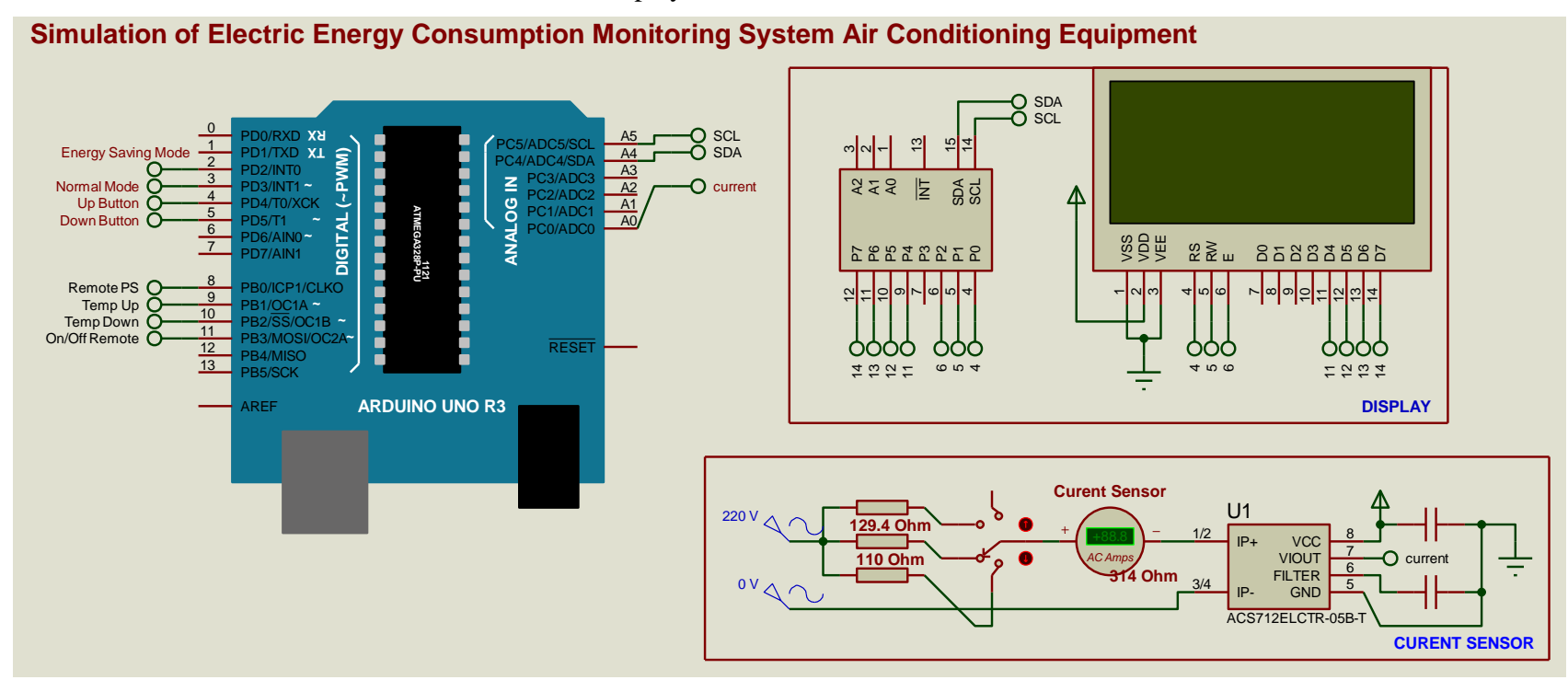

Fig. 3 System Design

\subsection{Software Making}

The software is made based on the system algorithm that has been generated. The process of making software, made through the Arduino IDE program. Program creation is shown in Figure 4.

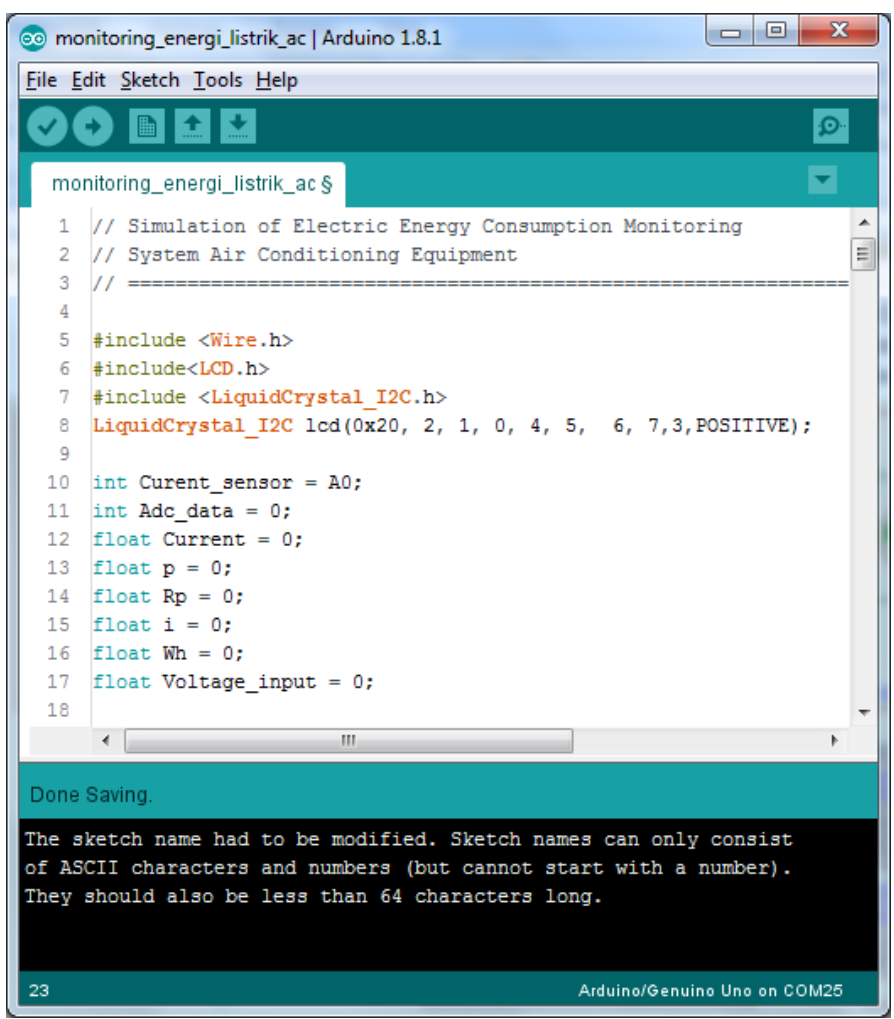

Fig. 4 Program creation

\section{RESULT AND DISCUSSION}

The system testing process is carried out through the Proteus simulation program, by embedding the program created based on the algorithm program via arduino IDE to arduino uno controller. Stages of system testing as follows:

\subsection{System Testing When First Activation}

When the system is first activated, the first part that is executed is the setup section, where in this section the system will configure the LCD display that is used as the information media. The system will then display information via the LCD display about the function of the system created. 
The system setup program section is as follows:

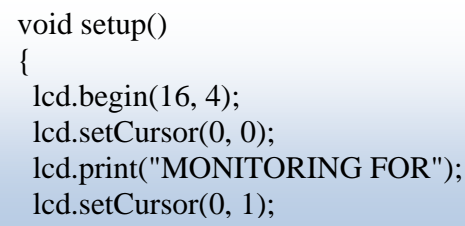

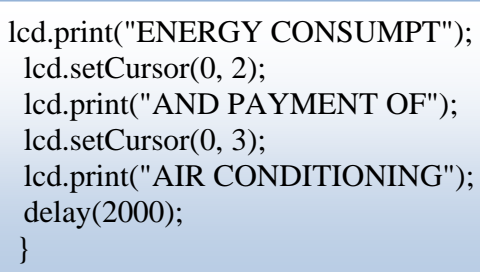

The initial display when the system is first activated is shown in Figure 5 .

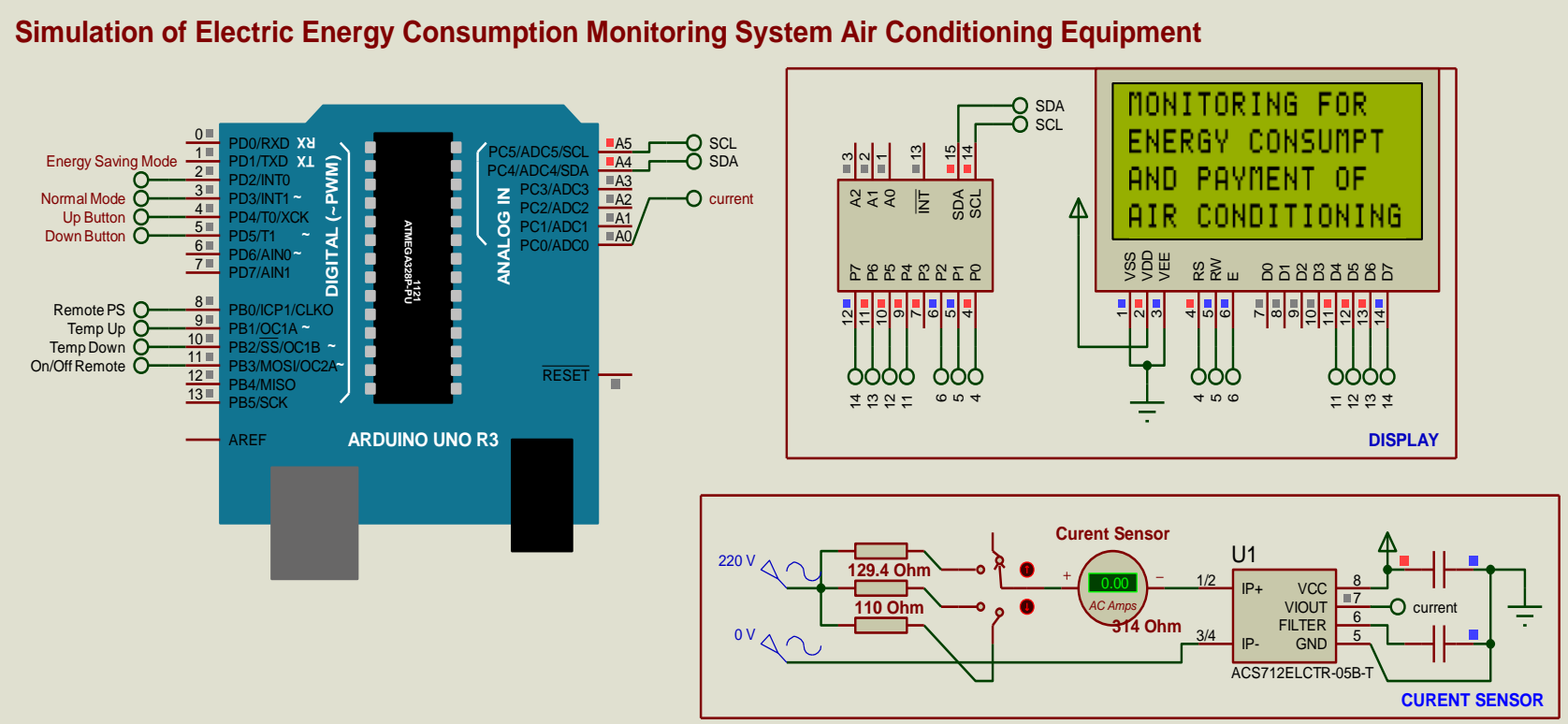

Fig. 4 Testing when the system was first activated

\subsection{Testing for the process of monitoring the electrical energy consumption of air conditioning equipment \\ After the setup process is complete, the system will enter the} current sensor reading section. In the current sensor reading section, the system will detect whether incoming data

Simulation of Electric Energy Consumption Monitoring System Air Conditioning Equipment

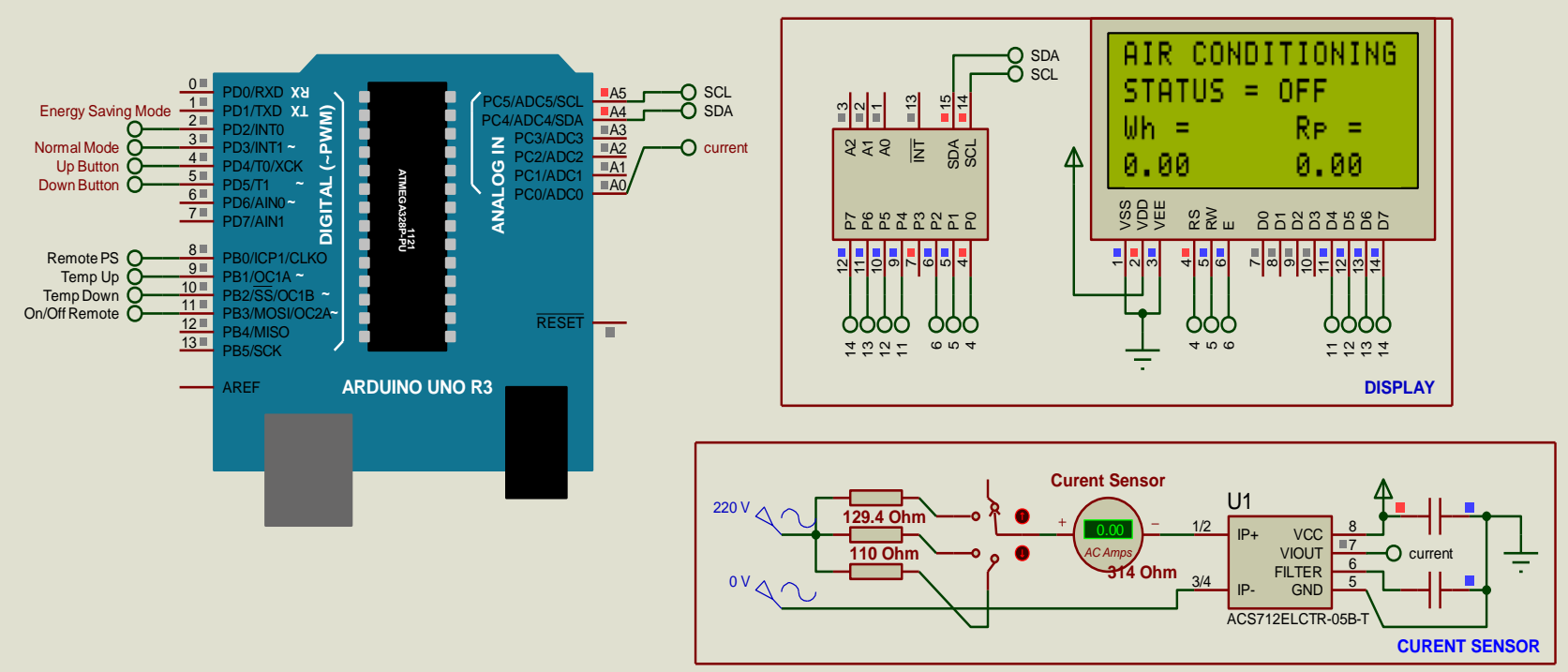

Fig. 4 Testing of conditions for air conditioning in the Off state 
The part of the program that functions to detect whether air conditioning is active or inactive is as follows:

\begin{tabular}{|l} 
void read_adc() \\
Data_adc = analogRead(Current_sensor); \\
if (Data_adc < 530) \\
lcd.clear(); \\
lcd.setCursor(0, 0); \\
lcd.print("AIR CONDITIONING"); \\
lcd.setCursor(0, 1); \\
lcd.print("STATUS = OFF"); \\
lcd.setCursor(0, 2); \\
lcd.print("Wh ="); \\
lcd.setCursor(0, 3); \\
String energy = String (Wh); \\
lcd.print(energy); \\
lcd.setCursor(10, 2); \\
lcd.print("Rp ="); \\
lcd.setCursor(10, 3); \\
String rupiah = String (Rp); \\
lcd.print(rupiah); \\
delay(1000); \\
\}
\end{tabular}

If the data received shows that there is a voltage value detected from the reading of the current sensor, then the program that is run is part of the program to convert the voltage value into a current value. The part of the program that functions to convert voltage values into current values is as follows:

\begin{tabular}{|l|}
\hline else \\
\{ \\
Voltage_input $=(($ Data_adc $* 5) / 1024) ;$ \\
Current $=(($ Voltage_input -2.5$) / 0.186) ;$ \\
delay $(300) ;$ \\
Calculate_Rp ()$;$
\end{tabular}

$$
\text { \} }
$$

After the current value is obtained, the system will run the program part to calculate the amount of electricity consumption and the price that must be paid to the operation of air conditioning equipment. Furthermore, the data from the processing of electrical energy consumption and the pay price of air conditioning equipment, will be informed to the LCD display. The program section for processing electrical energy consumption data and the pay price of air conditioning equipment are as follows:

void Calculate_Wh_Rp()
$\mathrm{p}=(220 *$ Current);
$\mathrm{i}=\mathrm{i}+\mathrm{p} ;$
$\mathrm{Wh}=((1.0 / 3600) * \mathrm{i}) ;$
$\mathrm{Rp}=((\mathrm{Wh} / 1000) * 1325) ;$
lcd.clear();
lcd.setCursor(0, 0);
lcd.print("AIR CONDITIONING");
lcd.setCursor(0, 1);
lcd.print("STATUS = ON");
lcd.setCursor(0, 2);
lcd.print("Wh =");
lcd.setCursor(0, 3);
String energy = String (Wh);
lcd.print(energy);
lcd.setCursor(10, 2);
lcd.print("Rp =");
lcd.setCursor(10, 3);
String rupiah = String (Rp);
lcd.print(rupiah);
delay(600);
let

The display for the process of monitoring electrical energy consumption and the pay price of air conditioning equipment, is shown in Figure 5. 


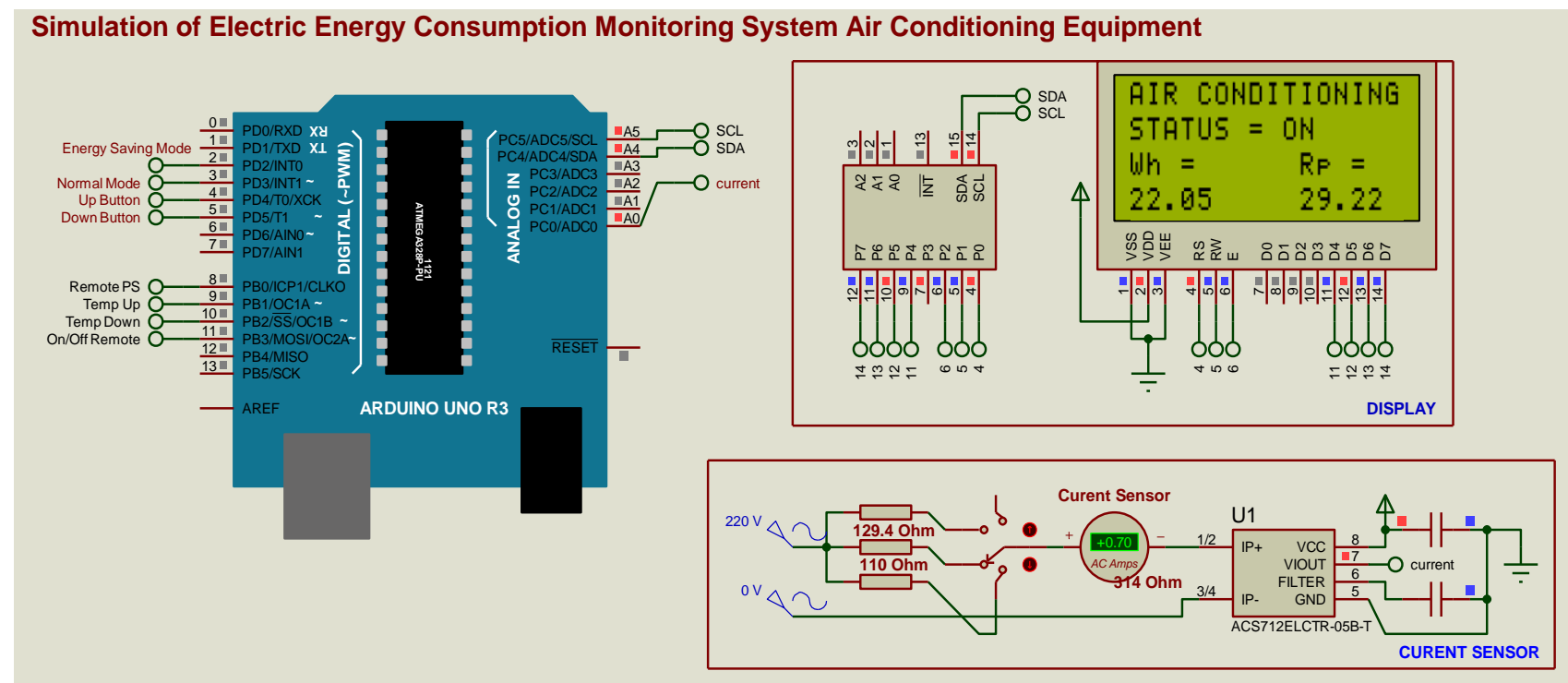

Fig. 4 Process of monitoring electrical energy consumption and the pay price of air conditioning equipment

\section{CONCLUSIONS}

From the results of the tests carried out, it can be concluded that the system created, in the form of a simulation system monitoring the consumption of electrical energy from air conditioning equipment, can monitor the consumption of electrical energy from air conditioning equipment, through reading the current sensor value. The reading of the current value will be processed by the controller, then inform it through the LCD display, as information on the consumption of electrical energy (wh) and the amount of price ( $\mathrm{Rp}$ ) that must be paid to the electricity consumption of air conditioning equipment. In the future, it is expected that the monitoring system method for electrical energy consumption of air conditioning equipment, is expected to be implemented directly to air conditioning equipment, so that users can find out how much electricity consumption from air conditioning equipment operation, so that users can optimize the operation of the equipment, so as to minimize the occurrence of electricity waste.

\section{ACKNOWLEDGMENTS}

Many thanks to the organizers of the International Journal of Computer Application (IJCA) which has provided an opportunity for authors to publish this paper and to the Ministry of Research and Technology who has funded this research so as to produce a scientific work as well as to the Manado State Polytechnic Institute as well Colleagues who have helped so much that the author can complete this writing.

\section{REFERENCES}

[1] Buntarto, "Service dan Reparasi AC", Graha Ilmu, Yogyakarta, 2009

[2] Handoko J, "Merawat dan Memperbaiki AC", Kawan Pustaka, Jakarta, 2009.

[3] A. G. Smith, "Introduction To Arduino", 2011.

[4] Sujadi, "Teori dan Aplikasi Mikrokontroler", Cetakan Pertama, Graha Ilmu, Yogyakarta, 2005.base Web Server", Electrical and Power Engineering (EPE), International Conference and Expocition on, 2014.
[5] Allegro mikrosistem.inc. "Datasheet ACS712".

[6] Husnawati, Rossi Passarella, Sutarno dan Rendyansyah, "Perancangan dan Simulasi Energi Meter Digital Satu Phasa Menggunakan Sensor Arus ACS712", JNTETI Vol. 2. No. 4, November 2013.

[7] Ilham, Amil Ahmad, and Ali Ramschie. "SISTEM MONITORING DAN KENDALI KERJA AIR CONDITIONING BERBASIS MIKROKONTROLLER ATmega 8535.", Jurnal Ristek Vol.2, No.1, Juni 2013.

[8] A. A. S. Ramschie, J. F. Makal, V. V. Ponggawa, "Method of Freon Leak Detection and Dirty Air Filter in Air Conditioning for Electrical Savings", International Journal of Computer Applications, Vol. 172 No.1, 2017.

[9] Ali A.S. Ramschie, Johan Makal, Veny Ponggawa, "Algorithms Air Conditioning Air Filter Detection System For Electric Energy Savings", International Journal of Computer Application (IJCA), Vol. 156 No. 8, 2016.

[10] M. Mossolly, K. Ghali, N. Ghaddar, "Optimal Control Strategy For a Multy-Zone Air Conditioning System Using The Genetic Algorithm", ELSEVIER Vol. 34, Issue 1, page 58-66, 2009.

[11] Chiou. C.B., Chu C.M. dan Lin, S.L. "The study of energisaving strategy for direct expansion air conditioning system 'Energi and Buildings 40. 16601665,2008 .

[12] Widell. K.N. dan Eikevik. T. "Reducing power consumption in multi -compressor refrigeration sistems" International Journal of Refrigeration 33. 88-94,2009.

[13] Zhou, Y.P., Wu, J.Y., Wang, R.Z. \& Shiochi, S.“Energi simulation in the variable refrigerant flow airconditioning sistem under cooling conditions" Energi and Buildings 39. 212-220, 2007. 